\title{
Efeito de épocas de semeadura sobre cultivares de girassol, no Sul do Estado do Tocantins ${ }^{1}$
}

\author{
Effects of sowing periods on sunflower cultivars in the South of the State of \\ Tocantins
}

\author{
Elonha Rodrigues dos Santos ${ }^{2 *}$, Hélio Bandeira Barros ${ }^{3}$, Aristóteles Capone ${ }^{3}$, Emerson de Castro Ferraz e $^{4}$ \\ Rodrigo Ribeiro Fidelis ${ }^{3}$
}

\begin{abstract}
Resumo - Objetivou-se com este trabalho avaliar o desempenho agronômico de cultivares de girassol (Helianthus annuus L.), semeados em diferentes épocas, nas condições ambientais da região Sul do Estado do Tocantins. O experimento foi conduzido no ano agrícola 2008/2009 em blocos casualizados em esquema fatorial 4 x 5 (quatro épocas de semeadura x cinco cultivares de girassol) com três repetições. Cada parcela foi constituída por quatro linhas de 5,0 m de comprimento, espaçadas de $0,80 \mathrm{~m}$ entre linhas e 0,20 m entre plantas na linha. Em todas as épocas de semeadura foram avaliadas as características, florescimento, altura de planta, diâmetro de caule, diâmetro de capítulo, aquênios normais, massa de mil grãos e produtividade de grãos. Houve interação significativa da época de semeadura com os cultivares avaliados para as seguintes características: florescimento, altura de planta e produtividade de grãos. Em relação às épocas de semeadura, em geral houve influência negativa para todas as características avaliadas nas épocas mais tardias, fato ocorrido pela presença de veranico no período crítico do desenvolvimento das plantas e a ocorrência de doenças, especialmente mancha de alternária. A primeira época de semeadura (novembro) apresentou maior produtividade com média superior a $3.000 \mathrm{~kg} \mathrm{ha}^{-1}$. Independente das épocas de semeadura os cultivares mais produtivos foram os híbridos Hélio 360 e Hélio 884 com média de 1.709 e $1.697 \mathrm{~kg} \mathrm{ha}^{-1}$ respectivamente.
\end{abstract}

Palavras-chave - Girassol. Semeadura. Grãos-produtividade.

\begin{abstract}
This study had as its objective, evaluating the agronomic performance of sunflower (Helianthus annuus L.) cultivars when sown at different times, under the environmental conditions in the south of the State of Tocantins. The experiment was carried out during the 2008/2009 agricultural year, in randomized blocks in a 4 x 5 factorial design (four sowing dates and five sunflower cultivars) with three replications. Each plot consisted of four rows $5.0 \mathrm{~m}$ in length, spaced $0.80 \mathrm{~m}$ apart with $0.20 \mathrm{~m}$ between plants. For all sowing dates, the characteristics evaluated were: flowering, plant height, stem diameter, head diameter, normal achenes, grain weight per thousand and grain yield. There was significant correlation of sowing dates with the evaluated cultivars for the traits of flowering, plant height and grain yield. In relation to periods of sowing, there was generally a negative influence on all evaluated traits for the later dates, due to an Indian summer causing moisture stress during the critical period of plant development and the occurrence of disease, especially alternaria leaf-spot. The first sowing period (November) showed higher productivity with an average of more than $3,000 \mathrm{~kg} \mathrm{ha}^{-1}$. Irrespective of sowing dates, the more productive cultivars were the hybrids Helio 360 and Helio 884, with an average of 1,709 and 1,697 $\mathrm{kg} \mathrm{ha}^{-1}$ respectively.
\end{abstract}

Key words - Sunflower. Sowing. Grain-productivity.

\footnotetext{
* Autor para correspondência

'Recebido para publicação em 23/04/2010; aprovado em 08/07/2011

Pesquisa desenvolvida pela Faculdade de Agronomia da Universidade Federal do Tocantins

2Programa de Pós-Graduação em Agronomia, Universidade de Brasília/UnB, Brasília-DF, Brasil, 70.910-900, elonharodrigues@yahoo.com.br

${ }^{3}$ Universidade Federal do Tocantins, Campus Universitário de Gurupi, Caixa Postal 66, Gurupi-TO, Brasil, 77.402-970, barroshb@uft.edu.br, fidelisrr@uft.edu.br, aristotelescapone@hotmail.com

${ }^{4}$ Bolsista de Iniciação Científica-CNPq, graduando do Curso de Agronomia, Universidade Federal do Tocantins, Campus Universitário de Gurupi,

Gurupi-TO, Brasil, 77.402-970, emerson-agro@hotmail.com
} 


\section{Introdução}

O girassol é tradicionalmente considerado como uma cultura de grande plasticidade, pois desenvolve-se bem em regiões de clima temperado, subtropical e tropical (BARNI et al., 1995). Apresenta elevada importância, pois produz óleo de boa qualidade e alto valor nutricional como alimento funcional tanto para humanos, quanto ruminantes, suínos e aves, além disso, pode ser utilizada para silagem como opção forrageira. Atualmente, está despertando grande interesse a nível mundial, pois representa uma alternativa de mercado para a produção de matéria-prima para obtenção de biocombustíveis (VILLALBA, 2008).

Mundialmente o girassol destaca-se como a quinta oleaginosa em produção de grãos, quarta em produção de farelo e terceira em produção de óleo. Os maiores produtores são: Rússia, Ucrânia, União Européia e Argentina (LAZZAROTTO et al., 2005). Essa cultura responde aproximadamente por $13 \%$ de todo óleo vegetal produzido no mundo e vem apresentando índices crescentes de produção e área plantada a nível mundial.

A cultura do girassol apresenta características desejáveis sob o ponto de vista agronômico como: ciclo curto, elevada qualidade e bom rendimento em óleo, o que o qualifica como uma boa opção aos produtores brasileiros (SILVA, et al. 2007b). Entretanto, no Brasil, essa cultura ainda ocupa área de cultivo restrita, sendo que dos 95.000 hectares cultivados na safra 2008/2009 aproximadamente 93.000 hectares foram cultivados no Centro Sul e apenas 2.600 hectares nas regiões Norte/Nordeste (CONAB, 2009).

Um dos fatores que contribui para esse baixo cultivo de girassol são as poucas informações disponíveis sobre cultivares adaptados e épocas de semeadura apropriadas para as diferentes regiões do país. Segundo Castro et al. (1997), a época de semeadura é o principal fator de sucesso da cultura do girassol, onde as exigências das plantas deverão ser atendidas, nas diferentes fases de desenvolvimento, reduzindo os riscos ocasionados por flutuações climáticas, principalmente por uma distribuição irregular das chuvas, os conhecidos veranicos e o aparecimento de doenças, especialmente após o florescimento assegurando assim uma boa produtividade.

Apesar de vários trabalhos terem sido realizados, no Brasil, para avaliar a época mais apropriada de semeadura de girassol, não existem dados sobre a época de semeadura adequada para o Estado do Tocantins, bem como informações sobre cultivares adaptados para esse Estado.

Nesse contexto, objetivo-se com este trabalho avaliar o desempenho de cultivares de girassol, semeados em diferentes épocas nas condições ambientais da região Sul do Estado do Tocantins.

\section{Material e métodos}

Os experimentos foram conduzidos no ano agrícola 2008/2009, na Universidade Federal do Tocantins, Campus Universitário de Gurupi, Estado do Tocantins, localizada a $11^{\circ} 43^{\prime}$ de latitude Sul e $49^{\circ} 04^{\prime}$ de longitude Oeste e altitude de $280 \mathrm{~m}$, em um Latossolo Vermelho Amarelo Distrófico (EMBRAPA, 1999).

As análises químicas e físicas do solo foram realizadas no Laboratório de Solos do Departamento de Solos da Universidade Federal do Tocantins e apresentaram as seguintes características: $\mathrm{pH}=4,6$; $\mathrm{Al}^{3+}+\mathrm{H}^{+}=4,9 \mathrm{cmol}_{\mathrm{c}} \mathrm{dm}^{-3} ; \mathrm{Ca}^{2+}+\mathrm{Mg}^{2+}=2,6 \mathrm{cmol}_{\mathrm{c}} \mathrm{dm}^{-3}$; $\mathrm{K}^{+}=0,1 \mathrm{cmol} \mathrm{dm}^{-3} ; \mathrm{P}=11,2 \mathrm{mg} \mathrm{dm}^{-3} ; \mathrm{V}=32,5 \% ; \mathrm{C}=$ $16,2 \mathrm{~g} \mathrm{dm}^{-3} ; \mathrm{SB}=2,5 \mathrm{cmol}_{\mathrm{c}} \mathrm{dm}^{-3} ; \mathrm{CTC}=5,1 \mathrm{cmol}_{\mathrm{c}} \mathrm{dm}^{-3}$; matéria orgânica: $16,2 \mathrm{~g} \cdot \mathrm{dm}^{-3}$; areia $=601,8 \mathrm{~g} \mathrm{~kg}^{-1}$; silte $=52,0 \mathrm{~g} \mathrm{~kg}^{-1}$; argila $=346,2 \mathrm{~g} \mathrm{~kg}^{-1}$.

O clima, Segundo o método de Thornthwaite, é do tipo Aw, clima úmido com moderada deficiência hídrica (SEPLAN, 2003). Durante o ciclo da cultura os dados climáticos foram coletados da Estação Meteorológica do Campus Universitário de Gurupi - TO, com distância aproximada de $50 \mathrm{~m}$ da área experimental, Figura 1.

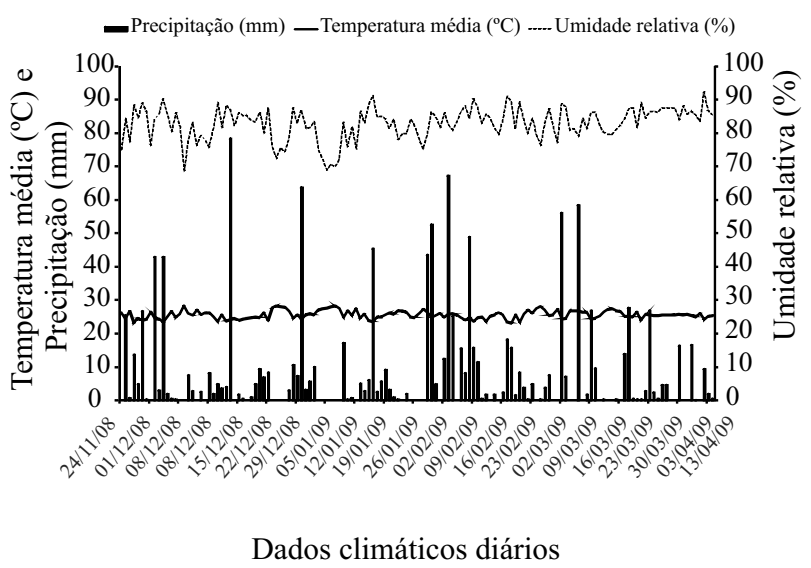

Figura 1 - Valores médios diários de temperaturas $\left({ }^{\circ} \mathrm{C}\right)$, total diário de precipitação pluvial $(\mathrm{mm})$ e valores médios diários da umidade relativa do ar (\%), ocorridas durante o período de 24 de novembro de 2008 a 13 de abril de 2009, Gurupi, TO

Os experimentos foram implantados sob sistema de plantio convencional. A calagem e as adubações de semeadura e de cobertura foram feitas de acordo com Castro e Farias (2005) baseando-se nos resultados da análise química do solo. Utilizou para correção da acidez do solo $1,2 \mathrm{t} \mathrm{ha}^{-1}$ de calcário dolonitico com PRNT de 
95\%. As adubações de base foram aplicadas no sulco de semeadura correspondendo a $60 \mathrm{~kg}$ de $\mathrm{P}_{2} \mathrm{O}_{5} \mathrm{ha}^{-1}, 60 \mathrm{~kg}$ de $\mathrm{K}_{2} \mathrm{O}$ ha $^{-1}$ e $20 \mathrm{~kg}$ de $\mathrm{N} \mathrm{ha}^{-1}$.

O delineamento experimental utilizado foi de blocos casualizados em esquema fatorial 4 x 5 (quatro épocas de semeadura $\mathrm{x}$ cinco cultivares de girassol), totalizando 20 tratamentos, com três repetições. Cada parcela foi constituída por quatro linhas de 5,0 m de comprimento, espaçadas de 0,80 m entre linhas e 0,20 entre plantas na linha. Somente as duas linhas centrais foram consideradas como área útil para as avaliações.

Os ensaios foram instalados em quatro épocas: 24/11/2008 (primeira época), 01/12/2008 (segunda época), 18/12/2008 (terceira época) e 30/12/2008 (quarta época). Foram utilizados cinco cultivares de girassol: Hélio 884 (H 884), Hélio 358 (H 358), Hélio 250 (H 250), Hélio 251 (H 3251) e Hélio 360 (H 360).

O desbaste foi realizado aos quinze dias após a emergência(DAE), deixando cinco plantas por metro linear. Aos trinta DAE, foi realizada a adubação nitrogenada de cobertura, na dose de $60 \mathrm{~kg}$ de $\mathrm{N} \mathrm{ha}^{-1}$. A adubação de Boro foi aplicada via foliar parcelada em duas vezes (aos 40 DAE e 50 DAE) totalizando em $1,5 \mathrm{~kg} \mathrm{ha}^{-1}$. Para controle de plantas daninhas foram realizadas capinas manuais aos 15 DAE e aos 30 DAE. Para o controle da mancha de alternária (Alternaria spp) foi utilizando o fungicida Difenoconazol na dosagem de $0,6 \mathrm{~L} \mathrm{ha}^{-1}$.

As características avaliadas foram: florescimento (F, em DAE): anotado quando $50 \%$ das plantas da parcela útil encontravam-se no estádio fenológico R4 (CONNOR;
HALL, 1997); altura da planta (AP, em cm): medida da base do solo até a inserção do capítulo, em cinco plantas competitivas da parcela útil; diâmetro do caule (DC, em $\mathrm{mm}$ ): medido a $10 \mathrm{~cm}$ do solo, em cinco plantas competitivas da parcela útil; diâmetro do capítulo (DC, em $\mathrm{cm})$ : média de cinco capítulos de cada parcela útil; aquênios normais (AN, em \%): obtida a partir da contagem do número de aquênios normais e chochos de cinco capítulos de cada parcela útil; massa de mil grãos ( $\mathrm{MG}$, em g): obtida pela contagem direta de 1.000 aquênios, pesado posteriormente em balança de precisão e produtividade de grãos (PROD, em $\mathrm{kg} \mathrm{ha}^{-1}$ ), foram consideradas todas as plantas da parcela útil, corrigida a $11 \%$ de umidade.

Realizou-se análise de variância individual, posteriormente a análise conjunta dos dados sendo as médias comparadas pelo teste de Tukey $(\mathrm{P} \leq 0,05)$ utilizando o aplicativo estatístico Genes (CRUZ, 1997).

\section{Resultados e discussão}

Verificou-se interação significativa entre os cultivares e as épocas de semeadura para as variáveis: florescimento, altura de plantas e produtividade de grãos (TAB. 1), indicando que os efeitos de genótipos e épocas de semeadura não explicam todas as variações encontradas, neste caso, realizou-se os desdobramentos para estas variáveis.

Para a característica florescimento (TAB. 2), houve diferença significativa apenas entre a terceira e quarta época de semeadura. Para a primeira e segunda época o

Tabela 1 - Resumo da análise de variância conjunta das características: florescimento (F), altura de planta (AP), diâmetro do caule (DC), diâmetro do capítulo (DCP), aquênios normais (AN), massa de mil grãos (MG) e produtividade de grãos (PROD) de cinco cultivares de girassol cultivados em quatro épocas de semeadura em Gurupi-TO, na safra 2008/2009

\begin{tabular}{lcccccccc}
\hline \multirow{2}{*}{ FV } & GL & \multicolumn{7}{c}{ Quadrado médio } \\
\cline { 2 - 8 } & & F & AP & DC & DCP & NA & MG & PROD \\
\hline BL/Cultivar & 8 & 1,9 & 11,6 & 4,7 & 3,1 & 63,9 & 29,5 & $8.118,2$ \\
Blocos & 2 & 2,6 & 0,5 & 2,3 & 0,6 & 61,5 & 16,5 & $7.673,5$ \\
BL x Época & 6 & 1,8 & 15,2 & 5,6 & 3,9 & 64,7 & 33,8 & $8.266,4$ \\
Cultivar (C) & 4 & $11,6^{\text {ns }}$ & $590,7^{*}$ & $3,9^{\text {ns }}$ & $7,5^{* *}$ & $55,6^{\mathrm{ns}}$ & $53,2^{*}$ & $152.317,6^{\mathrm{ns}}$ \\
Épocas (E) & 3 & $153,9^{* *}$ & $2.366,4^{* *}$ & $280,0^{* *}$ & $61,9^{* *}$ & $2.345,4^{*}$ & $887,7^{* *}$ & $24.939 .728,5^{* *}$ \\
C x E & 12 & $4,4^{* *}$ & $170,9^{* *}$ & $1,7^{\mathrm{ns}}$ & $0,7^{\mathrm{ns}}$ & $55,5^{\mathrm{ns}}$ & $10,7^{\mathrm{ns}}$ & $178.349,4^{* *}$ \\
Resíduo & 32 & 1,2 & 92,1 & 1,5 & 1,0 & 40,6 & 13,1 & $23.216,2$ \\
\hline Média & & 3,1 & 162,7 & 21,5 & 15,8 & 76,6 & 35,7 & $1.599,8$ \\
C.V. (\%) & 2,1 & 3,6 & 5,7 & 6,4 & 8,3 & 11,3 & 9,5 \\
\hline
\end{tabular}

** Significativo $(\mathrm{P} \leq 0,01)$; * Significativo $(\mathrm{P} \leq 0,05)$; ${ }^{\text {ns }}$ Não significativo pelo teste $\mathrm{F}$, respectivamente 
florescimento ocorreu em média aos 55 DAE. A quarta época destacou-se pelo encurtamento do período vegetativo (49 DAE), com redução média de sete dias em relação à segunda época (56 DAE). O cultivar que apresentou maior variação entre as épocas avaliadas foi o $\mathrm{H} 884$, sendo constatada uma diferença de onze dias para o florescimento entre a segunda e a quarta época de semeadura.
A redução da fase vegetativa na quarta época pode ter ocorrido pela distribuição irregular de chuvas durante o mês de janeiro (FIG. 1), onde foram verificadas frequentes estiagens ou baixa precipitação, aliados à baixa capacidade de retenção de água do solo (60\% areia) no período em que as plantas encontravam-se no início da fase vegetativa (oito dias após a emergência).

Tabela 2 - Valores médios das características de florescimento (DAE), altura de planta (cm), diâmetro do caule (mm) e diâmetro do capítulo (cm) de cinco cultivares de girassol cultivados em quatro épocas de semeadura em Gurupi-TO, safra 2008/2009

\begin{tabular}{|c|c|c|c|c|c|}
\hline \multirow[b]{2}{*}{ Cultivares } & \multicolumn{4}{|c|}{ Épocas de semeadura } & \multirow[b]{2}{*}{ Média } \\
\hline & $\begin{array}{l}\text { Primeira época } \\
24 / 11 / 2008\end{array}$ & $\begin{array}{c}\text { Segunda época } \\
01 / 12 / 2008\end{array}$ & $\begin{array}{c}\text { Terceira época } \\
18 / 12 / 2008\end{array}$ & $\begin{array}{l}\text { Quarta época } \\
30 / 12 / 2008\end{array}$ & \\
\hline \multicolumn{6}{|c|}{ Florescimento (DAE) } \\
\hline Н 884 & $58,00 \mathrm{Aa}$ & $59,00 \mathrm{Aa}$ & $54,00 \mathrm{Ba}$ & $48,00 \mathrm{Ca}$ & 55,00 \\
\hline Н 358 & $56,00 \mathrm{Aab}$ & $55,00 \mathrm{Ab}$ & $52,00 \mathrm{Ba}$ & $50,00 \mathrm{Ca}$ & 53,00 \\
\hline Н 250 & $54,00 \mathrm{Ab}$ & $55,00 \mathrm{Ab}$ & $52,00 \mathrm{Ba}$ & $50,00 \mathrm{Ca}$ & 53,00 \\
\hline Н 251 & $55,00 \mathrm{Ab}$ & $55,00 \mathrm{Ab}$ & $52,00 \mathrm{Ba}$ & $48,00 \mathrm{Ca}$ & 52,00 \\
\hline Н 360 & $55,00 \mathrm{Ab}$ & $55,00 \mathrm{Ab}$ & $52,00 \mathrm{Ba}$ & $49,00 \mathrm{Ca}$ & 53,00 \\
\hline Média & 54,00 & 56,00 & 52,00 & 49,00 & \\
\hline \multicolumn{6}{|c|}{ Altura de planta $(\mathrm{cm})$} \\
\hline H 884 & $178,38 \mathrm{Aa}$ & $194,13 \mathrm{Aa}$ & $192,66 \mathrm{Aa}$ & $128,06 \mathrm{Ba}$ & 173,30 \\
\hline Н 358 & $169,53 \mathrm{Aa}$ & $179,40 \mathrm{Aab}$ & $180,46 \mathrm{Aa}$ & $128,06 \mathrm{Ba}$ & 164,36 \\
\hline Н 250 & $172,86 \mathrm{Aa}$ & $160,00 \mathrm{Ab}$ & $170,40 \mathrm{Aa}$ & $113,00 \mathrm{Ba}$ & 154,04 \\
\hline Н 251 & $171,26 \mathrm{Aa}$ & 172,66 Aab & $188,33 \mathrm{Aa}$ & $108,66 \mathrm{Ba}$ & 160,22 \\
\hline H 360 & $175,73 \mathrm{Aa}$ & $172,13 \mathrm{Aab}$ & $176,20 \mathrm{Aa}$ & $121,26 \mathrm{Ba}$ & 161,33 \\
\hline Média & 173,55 & 175,66 & 181,61 & 119,81 & \\
\hline \multicolumn{6}{|c|}{ Diâmetro do caule (mm) } \\
\hline H 884 & 22,60 & 21,13 & 23,53 & 14,94 & $20,55 \mathrm{a}$ \\
\hline Н 358 & 24,26 & 23,06 & 24,60 & 15,40 & $21,83 \mathrm{a}$ \\
\hline Н 250 & 24,66 & 23,20 & 24,33 & 15,80 & $22,00 \mathrm{a}$ \\
\hline Н 251 & 24,00 & 22,26 & 25,60 & 13,73 & $21,40 \mathrm{a}$ \\
\hline H 360 & 25,06 & 21,86 & 23,86 & 15,93 & $21,68 \mathrm{a}$ \\
\hline Média & $24,12 \mathrm{~A}$ & $22,31 \mathrm{~B}$ & $24,38 \mathrm{~A}$ & $15,16 \mathrm{C}$ & \\
\hline \multicolumn{6}{|c|}{ Diâmetro do capítulo $(\mathrm{cm})$} \\
\hline H 884 & 17,06 & 14,50 & 14,86 & 12,76 & $14,80 \mathrm{~b}$ \\
\hline Н 358 & 18,00 & 15,46 & 15,66 & 12,86 & $15,50 \mathrm{ab}$ \\
\hline H 250 & 18,00 & 15,53 & 15,03 & 13,46 & $15,50 \mathrm{ab}$ \\
\hline Н 251 & 18,80 & 17,13 & 17,10 & 13,90 & $16,73 \mathrm{a}$ \\
\hline H 360 & 19,93 & 16,26 & 15,76 & 13,93 & $16,47 \mathrm{a}$ \\
\hline Média & $18,36 \mathrm{~A}$ & $15,78 \mathrm{~B}$ & $15,68 \mathrm{~B}$ & $13,38 \mathrm{C}$ & \\
\hline
\end{tabular}

* Médias seguidas de mesma letra minúscula na coluna e maiúscula nas linhas não diferem pelo teste de Tukey, ao nível de 5\% 
Essas estiagens ocorridas durante os períodos chuvosos são denominadas de veranicos e são freqüentes nessa região durante essa época do ano e podem interferir negativamente no desenvolvimento da cultura, dependendo da fase fenológica em que esta se encontra. Segundo Santos et al. (2002) um dos principais fatores responsáveis pela variação de desenvolvimento da cultura do girassol, são as variações das precipitações ocorridas durante o cultivo.

Analisando os cultivares dentro das respectivas épocas de semeadura (TAB. 2), observou-se que na primeira época os cultivares $\mathrm{H} 884$ e $\mathrm{H} 358$ apresentaram maior duração da fase vegetativa. O H 884 teve o mesmo comportamento na segunda época, florindo aos 59 DAE e diferindo dos demais cultivares testados, que foram em média quatro dias mais precoces. Para a terceira e quarta época não ocorreu diferença significativa entre os cultivares, contudo, houve uma tendência na redução no número de dias para o florescimento para todos os cultivares.

Para altura de plantas não foram verificadas diferenças significativas entre as três primeiras épocas de semeadura (TAB. 2). Para a quarta época, houve redução significativa em média de 31,$0 ; 32,8$ e $34,0 \%$ em relação à primeira, segunda e terceira épocas, respectivamente. Essa estatura reduzida pode ser justificada, pela distribuição irregular de chuvas durante o mês de janeiro (veranico). Segundo Fageria (1998), o estresse hídrico tem efeito negativo no crescimento das plantas causando redução de vários processos fisiológicos e bioquímicos na planta, como na fotossíntese, perdas no turgor afetando as taxas de expansão celular, resultando na redução do crescimento, elongação do caule e da expansão foliar.

Quanto ao desempenho dos cultivares para altura de planta, entre as épocas de semeadura avaliadas, observou-se efeito significativo para segunda época, onde o cultivar $\mathrm{H}$ 250 obteve a menor altura $(160,0 \mathrm{~cm})$. O cultivar H 884 destacou-se durante as épocas de semeaduras avaliadas por apresentar maior altura média de plantas, com $173,3 \mathrm{~cm}$.

Smiderle et al. (2005) avaliando cultivares de girassol em duas épocas de semeadura em Roraima, obtiveram para primeira época, realizada no mês de janeiro, uma altura média de 169,0 cm sendo portanto, inferior aos resultados observados nas três primeiras épocas e superior à quarta época da presente pesquisa $(173,5 ; 175,6 ; 181,6$ e $119,8 \mathrm{~cm})$.

A terceira época de semeadura proporcionou maior altura de plantas e esses valores foram similares aos obtidos por Rezende et al. (2003), ao estudar o efeito da densidade de semeadura de diferentes cultivares de girassol, na população de 40.000 plantas por hectare em Lavras, Minas Gerais. Mello et al. (2006) ao analisar três épocas de semeadura de girassol no Rio Grande do Sul, verificaram valores médios de $125,0 \mathrm{~cm}$ no plantio realizado em novembro e esses valores se aproximaram aos encontrados na quarta época de semeadura do presente estudo.

Não houve diferença significativa para as médias de diâmetro do caule entre a primeira e terceira épocas de semeadura (TAB. 2). Para a quarta época verificou-se uma redução média de 37,1; 32,0 e 37,8\% em relação à primeira, segunda e terceira épocas de semeadura, respectivamente. Não foram constatadas diferenças entre os cultivares para a característica avaliada.

Os maiores valores para diâmetro do capítulo foram observados na primeira época de semeadura (TAB. 2). Notou-se ainda uma tendência de decréscimo no diâmetro do capítulo com o retardamento das semeaduras em relação a novembro. Essa redução observada na segunda e terceira época pode ser decorrente da infecção causada pela mancha de alternária. Quanto à quarta época, a redução do diâmetro pode ter ocorrido devido à deficiência hídrica ocasionada pelo veranico quando as plantas encontravam-se no inicio do período vegetativo, o que afetou todo o desenvolvimento.

Entre os cultivares avaliados o $\mathrm{H} 884$ foi o que apresentou menor diâmetro do capítulo, sendo significativamente inferior aos demais cultivares. Essa diferença pode ser decorrente do ciclo mais tardio, que o expôs à mancha de alternária por maior período, afetando de forma significativa seu desenvolvimento.

As plantas da segunda e terceira épocas de semeadura foram infectadas pela mancha de alternária no final da fase vegetativa e início da fase reprodutiva, período esse que coincidiu com os maiores índices pluviométricos durante o mês de fevereiro com $305 \mathrm{~mm}$ de precipitação ocorridos entre os dias cinco a dezessete de fevereiro, assim essa doença foi favorecida pelas altas freqüências pluviométricas e pelo acumulo de água sobre as folhas, associadas às temperaturas mais elevadas (FIG. 1). Amabile et al. (2002) ao avaliarem a severidade da mancha de alternária em genótipos de girassol em duas épocas de semeadura em Planaltina-DF, constataram que essa doença foi favorecida pela alta umidade relativa do ar e pelo acumulo de precipitação ocorridas durante o ciclo da cultura.

$\mathrm{Na}$ quarta época de semeadura o fator que pode ter prejudicado o pleno desenvolvimento das plantas foi à limitação hídrica em que a cultura foi submetida na fase inicial do desenvolvimento, que interferiu negativamente em todo o processo de desenvolvimento da planta, uma vez que as plantas dessa época não foram severamente infectadas pela mancha de alternária devido às condições ambientais desfavoraveis, principalmente após o florescimento. 
Os valores médios observados na primeira época de semeadura para diâmetro do capítulo, aproximam-se aos encontrados por Tomich et al. (2003) ao avaliarem 12 híbridos e uma variedade de girassol cultivados no período de safrinha em Sete Lagoa, Minas Gerais.

Na Tabela 3, verificou-se diferença significativa para porcentagem de aquênios normais entre as épocas de semeadura, sendo que a primeira época obteve os maiores valores para essa característica, em média de 92\%. Não foram constatadas variações no comportamento dos cultivares para a característica avaliada demonstrando, assim, uma homogeneidade destes cultivares às variações ambientais e fitossanitárias encontradas durante a condução do experimento.

A redução observada para porcentagem de aquênios normais na segunda e terceira épocas de semeadura podem estar associadas à presença da mancha de alternária, que contribuiu para o chochamento dos aquênios, além de promover a senecência precoce das folhas, interferindo assim, na translocação dos fotoassimilados para os grãos.

Os valores médios obtidos para porcentagem de aquênios normais neste trabalho foram de $76 \%$ e aproximamse aos encontrados por Amorim et al. (2008) em estudos de correlações e análises de trilha em girassol em São Paulo, onde obtiveram uma média de $75 \%$ de grãos normais.

Para massa de mil grãos foi verificada uma variação média de 30,4 a 47,0 g entre a terceira e primeira épocas de semeadura (TAB. 3). Os valores obtidos na primeira época foram significativamente superiores às demais épocas de semeadura avaliadas. Verificou-se, ainda que entre os cultivares testados o híbrido H 250 apresentou o menor desempenho.

Tabela 3 - Valores médios das características de aquênios normais (\%), massa de mil grãos (g) e produtividade de grãos $\left(\mathrm{kg} \mathrm{ha} \mathrm{a}^{-1}\right)$ de cinco cultivares de girassol cultivados em quatro épocas de semeadura em Gurupi-TO, safra 2008/2009

\begin{tabular}{|c|c|c|c|c|c|}
\hline \multirow[b]{2}{*}{ Cultivares } & \multicolumn{4}{|c|}{ Épocas de semeadura } & \multirow[b]{2}{*}{ Média } \\
\hline & $\begin{array}{c}\text { Primeira época } \\
24 / 11 / 2008\end{array}$ & $\begin{array}{c}\text { Segunda época } \\
01 / 12 / 2008 \\
\end{array}$ & $\begin{array}{c}\text { Terceira época } \\
18 / 12 / 2008 \\
\end{array}$ & $\begin{array}{c}\text { Quarta época } \\
30 / 12 / 2008 \\
\end{array}$ & \\
\hline \multicolumn{6}{|c|}{ Aquênios normais (\%) } \\
\hline H 884 & 94,00 & 80,00 & 59,00 & 68,00 & $75,25 \mathrm{a}$ \\
\hline Н 358 & 96,00 & 88,00 & 66,00 & 66,00 & $79,00 \mathrm{a}$ \\
\hline Н 250 & 93,00 & 81,00 & 70,00 & 67,00 & $77,75 \mathrm{a}$ \\
\hline Н 251 & 86,00 & 85,00 & 67,00 & 74,00 & $78,00 \mathrm{a}$ \\
\hline H 360 & 91,00 & 77,00 & 67,00 & 60,00 & $73,75 \mathrm{a}$ \\
\hline Média & $92,00 \mathrm{~A}$ & $82,00 \mathrm{~B}$ & $64,00 \mathrm{C}$ & $67,00 \mathrm{C}$ & \\
\hline \multicolumn{6}{|c|}{ Massa de mil grãos (g) } \\
\hline Н 884 & 51,79 & 33,49 & 30,72 & 35,00 & $37,75 \mathrm{a}$ \\
\hline Н 358 & 46,12 & 35,26 & 31,17 & 29,14 & $35,42 \mathrm{ab}$ \\
\hline Н 250 & 43,68 & 28,80 & 28,26 & 28,17 & $32,23 \mathrm{c}$ \\
\hline Н 251 & 45,84 & 36,78 & 30,52 & 33,95 & 36,77 a \\
\hline Н 360 & 47,72 & 34,37 & 31,36 & 31,44 & $36,22 \mathrm{ab}$ \\
\hline Média & $47,03 \mathrm{~A}$ & $33,74 \mathrm{~B}$ & $30,40 \mathrm{~B}$ & $31,54 \mathrm{~B}$ & \\
\hline \multicolumn{6}{|c|}{ Produtividade de grãos $\left(\mathrm{kg} \mathrm{ha}^{-1}\right)$} \\
\hline H 884 & $3.598 \mathrm{Aab}$ & $1.171 \mathrm{Bc}$ & $712 \mathrm{Cb}$ & $594 \mathrm{Ca}$ & 1.697 \\
\hline H 358 & $3.539 \mathrm{Abc}$ & $1.626 \mathrm{Ba}$ & $1.102 \mathrm{Ca}$ & $530 \mathrm{Da}$ & 1.567 \\
\hline Н 250 & 3.296 Acd & $959 \mathrm{Bd}$ & $897 \mathrm{BCab}$ & $653 \mathrm{Ca}$ & 1.451 \\
\hline Н 251 & $3.135 \mathrm{Ad}$ & $1.465 \mathrm{Bab}$ & $1.106 \mathrm{Ca}$ & $772 \mathrm{Da}$ & 1.619 \\
\hline H 360 & $3.875 \mathrm{Aa}$ & $1.313 \mathrm{Bbc}$ & $1.045 \mathrm{Ba}$ & $600 \mathrm{Ca}$ & 1.709 \\
\hline Média & 3.489 & 1.307 & 973 & 630 & \\
\hline
\end{tabular}

* Médias seguidas de mesma letra minúscula na coluna e maiúscula nas linhas não diferem pelo teste de Tukey, ao nível de 5\% 
Os valores médios para massa de mil grãos observados no presente estudo, para o cultivar H 251 corroboram aos obtidos por Silva et al. (2007a), ao estudarem o crescimento e a produtividade de girassol em diferentes lâminas de água em Lavras.

Backes et al. (2008) estudaram cultivares de girassol em Santa Catarina e obtiveram uma média de 46,3 g para massa de mil grãos, esses valores assemelharamse aos resultados obtidos para os cultivares avaliados na primeira época, que apresentaram uma média de 47,0 g. Quanto às demais épocas os valores médios obtidos neste experimento $(32,0 \mathrm{~g})$ corroboraram aos observados por Amorim et al. (2008) na avaliação de girassol em Campinas-SP.

A maior produtividade de grãos foi observada para a primeira época de semeadura com valor médio de $3.489 \mathrm{~kg} \mathrm{ha}^{-1}$, sendo significativamente superior às demais épocas (TAB. 3). Para a segunda época, verificou-se uma redução de $62,5 \%$ em relação à primeira época (equivalente a $2.182 \mathrm{~kg} \mathrm{ha}^{-1}$ ). Comparando a terceira época à segunda época, notou-se semelhança na produtividade de grãos apenas para os cultivares H 250 e H 360. Quanto à quarta época verificou-se uma redução média na produção de grãos de 82,0; 51,8 e $35,2 \%$ em relação à primeira, segunda e terceira época de semeadura, respectivamente.

Analisando a produtividade de grãos dos cultivares dentro de cada época de semeadura (TAB. 3), observou-se que na primeira época ocorreu uma variação de $740 \mathrm{~kg} \mathrm{ha}^{-1}$ entre os cultivares H 360 e H 251, o primeiro obteve maior produtividade de grãos com $3.875 \mathrm{~kg} \mathrm{ha}^{-1} \mathrm{e}$ igualou-se significativamente ao cultivar H 884. Na segunda época os cultivares H 358 foram os mais produtivos. Para a terceira época o cultivar H 884 foi significativamente inferior aos demais, entretanto, não diferiu significativamente do H 250. A variação entre os cultivares nesta época de semeadura foi de $394 \mathrm{~kg} \mathrm{ha}^{-1}$. Na quarta época, não houve superioridade significativa de nenhum dos cultivares testados.

A produtividade de grãos observada na primeira época de semeadura assemelham aos resultados obtidos por Smiderle et al. (2005) em Roraima, onde verificaram produtividade acima de $3.000 \mathrm{~kg} \mathrm{ha}^{-1} \mathrm{em}$ dois dos cultivares de girassol testados. Quanto a segunda época mesmo apresentado redução na produtividade, ainda aproximouse aos resultados de Grunvald et al. (2008) ao estudarem a adaptabilidade e estabilidade de genótipos de girassol no Brasil Central, onde a produtividade média verificada para os cultivares testados em Palmas-TO foi de $1.395 \mathrm{~kg} \mathrm{ha}^{-1}$.

Neste trabalho observou-se uma redução gradativa e significativa para produtividade em relação às épocas de semeadura, sendo que a primeira época foi em média $62 ; 72$ e $82 \%$ superior à segunda, terceira e quarta épocas de semeadura, respectivamente. Essa constatação pode ser justificada pela ocorrência de mancha de alternária no experimento, que afetou negativamente todos os cultivares principalmente na segunda e terceira épocas de semeadura. Salustiano et al. (2005), verificaram que a patogenicidade de Alternaria helianthi no girassol causa redução no número de sementes normais por capítulo, massa de mil grãos e conseqüentemente na produção.

Verificou-se na quarta época que o estresse hídrico (veranico) ocorrido no início do período vegetativo afetou negativamente todas as características avaliadas incluindo a produção final de grãos.

\section{Conclusões}

1. A primeira época de semeadura (novembro) apresentou produtividade superior a $3.000 \mathrm{~kg} \mathrm{ha}^{-1}$;

2. Independente das épocas de semeadura os cultivares mais produtivos foram $\mathrm{H} 360$ e $\mathrm{H} 884$;

3. O potencial produtivo da segunda e terceira épocas de semeaduras foi comprometido devido a forte incidência da mancha de alternária pela Alternaria sp;

4. A quarta época de semeadura, realizada no final de dezembro (30/12/2008) foi fortemente afetada pela ocorrência de veranico durante o mês de janeiro.

\section{Referências}

AMABILE, R. F.; VASCONCELOS, C. M.; GOMES, A. C. Severidade da mancha-de-alternária em cultivares de girassol na região do Cerrado do Distrito Federal. Pesquisa Agropecuária Brasileira, v. 37, n. 03, p. 251-257, 2002.

AMORIM, E. P. et al. Correlações e análises de trilha em girassol. Bragantia, v. 67, n. 02, p. 307-316, 2008.

BACKES, R. L. et al. Desempenho de cultivares de girassol em duas épocas de plantio de safrinha no planalto norte catarinense. Scientia Agrária, v. 09, n. 01, p. 41-48, 2008.

BARNI, N. A. et al. Análise de crescimento do girassol em resposta a cultivares, níveis de adubação e épocas de semeadura. Pesquisa Agropecuária Gaúcha, v. 01, n. 02, p. 167-184, 1995.

CASTRO, C. et al. A cultura do girassol. Londrina: Embrapa, CNPSo, 1997. 36 p. (Circular Técnica, 13).

CASTRO, C.; FARIAS, J. R. B. Ecofisiologia do girassol. In: LEITE, R. M. V. B.; BRIGHENTI, A. M.; CASTRO, C. (Ed.). Girassol no Brasil. Londrina: Embrapa Soja, 2005. p. 163-218.

COMPANHIA NACIONAL DE ABASTECIMENTO (CONAB). Acompanhamento da safra brasileira de grãos 
- Safra 2008/2009, quarto levantamento. Disponível em: $<$ http://www.conab.gov.br>. Acesso em: 05 maio 2009.

CONNOR, J. D.; HALL, A. J. Sunflower physiology. In: SCHNEIDER, A. A. Sunflower technology and production. Madison: ASA/CSSA/SSSA, 1997. p. 113-181. (Series of monographs, 35).

CRUZ, C. D. GENES: aplicativo computacional em genética e estatística. Viçosa: UFV, 1997. 442 p.

EMPRESABRASILEIRADEPESQUISAAGROPECUÁRIA (EMBRAPA). Centro Nacional de Pesquisa de Solos. Sistema brasileiro de classificação de solos. Brasília: EMBRAPA, 1999. $412 \mathrm{p}$.

FAGERIA, N. F. Otimização da eficiência nutricional na produção das culturas. Revista Brasileira de Engenharia Agrícola e Ambiental, v. 02, n. 01, p. 6-16, 1998.

GRUNVALD, A. K. et al. Adaptabilidade e estabilidade de genótipos de girassol no Brasil Central. Pesquisa Agropecuária Brasileira, v. 43, n. 11, p. 1483-1493, 2008.

LAZZAROTO, J. et al. O agronegócio do girassol no mundo e no Brasil. In: LEITE, R. M. V. B. C. et al. Girassol no Brasil. 2. ed. Londrina: Embrapa Soja, 2005. p. 15-42.

MELLO, R. et al. Características fenológicas, produtivas e qualitativas de híbridos de girassol em diferentes épocas de semeadura para produção de silagem. Revista Brasileira de Zootecnia, v. 35, n. 03, p. 672-682, 2006.

REZENDE, A. V. et al. Efeito da densidade de semeadura sobre a produtividade e composição bromatológica de silagens de girassol (Helianthus annuus L.). Ciência e Agrotecnologia, p. 1672-1678, 2003. Edição especial.
SALUSTIANO, M. E.; MACHADO, J. C.; PITTIS, J. E. Patogenicidade de Alternaria helianthi (HANSF.) e Alternaria zinniae (Pape) ao girassol a partir de sementes. Revista Brasileira de Sementes, v. 27, n. 01, p. 138-143, 2005.

SEPLAN. Secretaria do Planejamento e Meio Ambiente. Atlas do Tocantins: subsídios ao planejamento da gestão territorial. 3 . ed. Palmas: SEPLAN, 2003. 49 p.

SANTOS, A. C. et al. Varabilidade temporal da precipitação pluvial: nível de nitrogênio no solo e produtividade de cultivares de girassol. Ciência Rural, v. 32, n. 05, p. 757-764, 2002.

SILVA, M. L. O. et al. Crescimento e produtividade do girassol cultivado na entressafra com diferentes lâminas de água. Revista Brasileira de Engenharia Agrícola e Ambiental, v. 11, n. 05, p. 482-488, 2007a.

SILVA, M. L. O. et al. Viabilidade técnica e econômica do cultivo de safrinha do girassol irrigado na região de Lavras, MG. Ciência e Agrotecnologia, v. 31, n. 01, p. 200-205, $2007 b$.

SMIDERLE, O. J.; MOURÃO JUNIOR, M.; GIANLUPPI, D. Avaliação de cultivares de girassol em savana de Roraima. Acta Amazônica, v. 35, n. 03, p. 331-336, 2005.

TOMICH, T. R. et al. Potencial forrageiro de cultivares de girassol produzidos na safrinha para ensilagem. Arquivo Brasileiro de Medicina Veterinária e Zootecnia, v. 55, n. 06, p. 756-762, 2003.

VILLALBA, E. O. H. Recomendação de nitrogênio, fósforo e potássio para girassol sob sistema plantio direto no Paraguai. 2008. 78 f. Dissertação (Mestrado em Ciências do Solo) Universidade Federal de Santa Maria, Santa Maria. 